\title{
Kotel Balkan - an oasis of the East Balkan geodiversity
}

\section{Котленският Балкан - оазис на георазнообразието в Източния Балкан}

\author{
Dimitar Sinnyovsky, Rumen Stoilov \\ Димитьр Синьовски, Румен Стоилов
}

University of Mining and Geology “St. Ivan Rilski”1700 Sofia; E-mails: dssinsky@gmail.com; rstoilov@gmail.com

\begin{abstract}
The East Balkan offers picturesque mountain landscapes predetermined by a remarkable geological diversity: caves, waterfalls, karst springs and precipices, fossil deposits, stratigraphical, paleontological, tectonic and fossil slump phenomena. In its most attractive part, the Kotel Balkan, there are 28 natural landmarks, 3 protected areas and 2 reserves. Expanding the inventory with purely geological sites, such as fossils, olistostromes, thrusts, geological cycles and events, complemented by many historical sites and intangible cultural heritage (Karakachan minority traditions, craft and folklore festivals), the region of Kotel has excellent preconditions for a geopark development.
\end{abstract}

Keywords: Kotel Balkan, landscapes, geodiversity, geosites, geopark “East Balkan”.

\section{Исторически предпоставки}

Boué (1840) най-напред споменава за „варовик с черен флинт“, в който са многобройните пещери на Котленския карст. Toula (1890) описва първите фосили, сред които емблематичният за Котел Orbitolina concava и геоложките феномени Талимташ (фиг. 1a, b), карстовия извор Котелка (фиг. 1c), Демиркапия (фиг. 1d), Разбойна и „найкрасивата сталактитова пещера на Балканите“ (Приказна) (фиг. 1h). Zlatarski $(1905,1906)$ отнася „орбитоидно-бриозойските“ флинтови варовици и ценоманските пясъчници с Orbitolina към медитеранския тип Горна Креда. Kockel (1927) нарича Източния Балкан „Флишки Балкан“, a Kossmat (в Kockel, 1927) схематизира разпространението на мезозойските и терциерните скали в профила по маршрута Сливен-Нейково-Котел. Роденият в Котел проф. Bakalov (1942) акцентира върху фосилните и тектонски феномени, а съвременните представи за сложния геоложки строеж на района са поставени от Entscheva \& Kănčev (1961), Kănčev (1964) и обобщени от Kanchev (1995a, b).

\section{Концепцията за геопарк „Източен Балкан“6}

Съгласно принципа на ,тематичното георазнообразие“ (Sinnyovsky et al., 2019) основната тема на всеки геопарк определя неговата идентичност, а второстепенните теми допълват неговото георазнообразие. Във фокуса на геопарк „Източен Балкан“ стоят карстовите ландшафти - пещери, скални венци, карстови извори и водопади, 28 от които присъстват в Регистьра на природните забележителности, допълнени от 3 защитени зони и 2 резервата. С особен приоритет в геопарка са геотопите с научна и историческа стойност за българската геология - фосилни находища, олистостроми, тектонски феномени, геоложки цикли и събития.

\section{Георазнообразие}

Геоложките феномени са групирани в няколко „клъстера“ със сходни геоконсервационни характеристики и общ достъп. Най-достъпни са геотопите от Котленската група, които са в рамките на гр. Котел и неговите близки околности: карстовият извор Котелка (парк „Изворите“), фосилните находища, олистолитите, природонаучният музей и средновековните църкви, построени с блокове от ценоманските пясъчници (фиг. 1d-f). Друга група геотопи са пещерите, западно от града, по долината на р. Сухойка: Дряновската, Духлото, Приказна, Билерника, Кървавата локва, Луцифер и Орловата пещера (фиг. 1g-i). 
Fig. $6 a$.

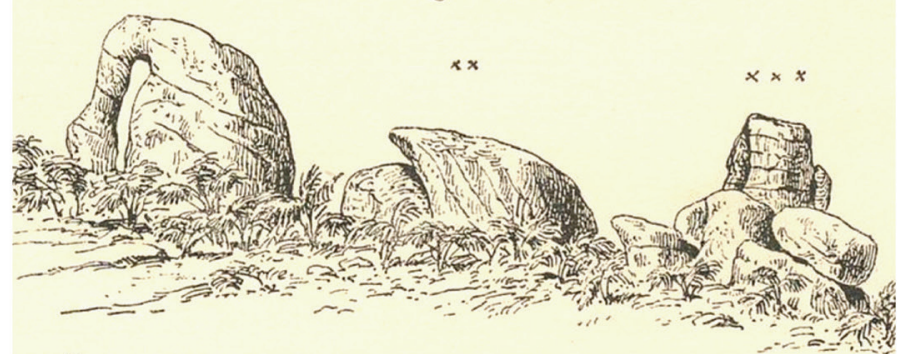

a

Die Sandsteinblöcke „Talim Tasch“ der Passhöhe von vorne.
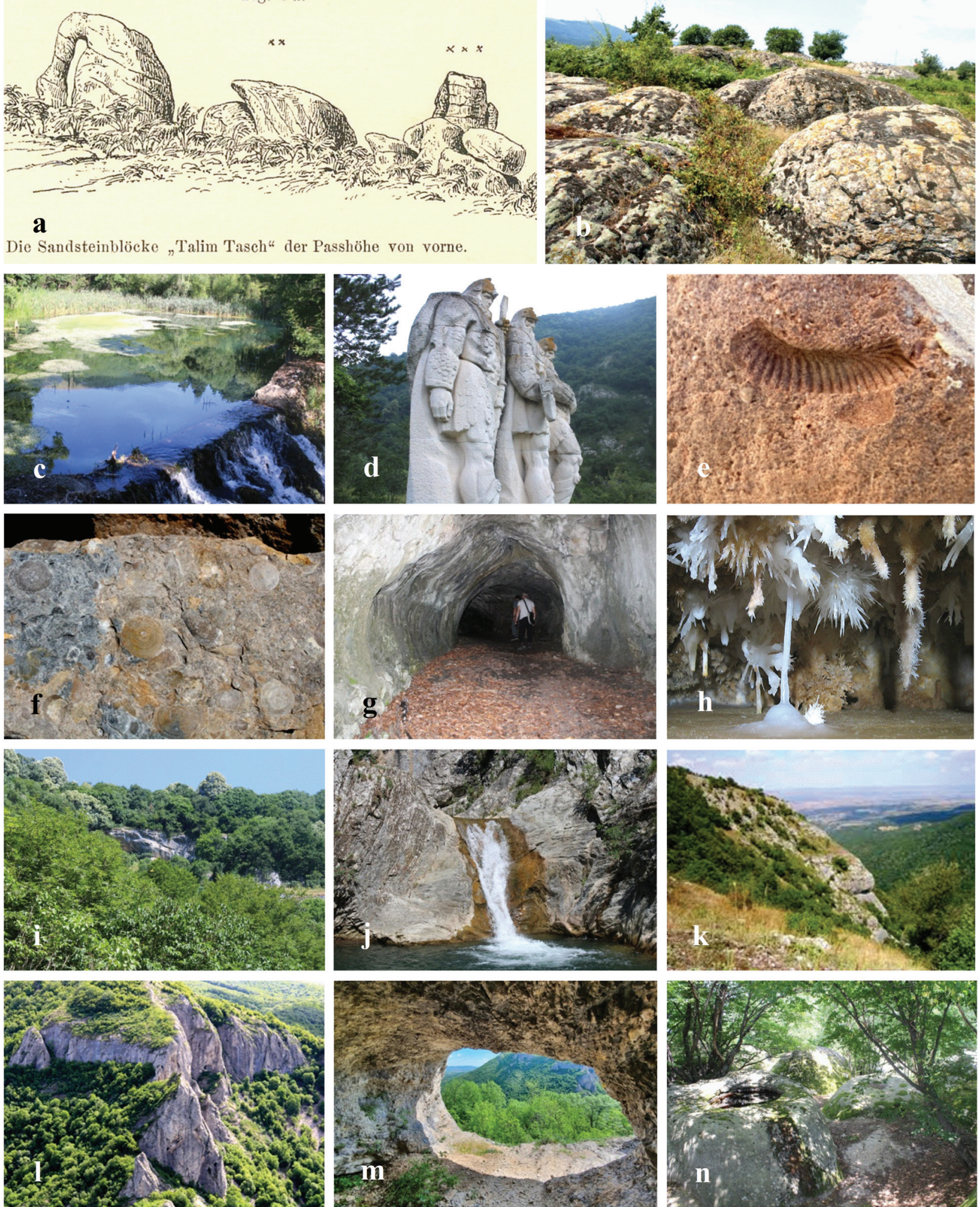

Фиг. 1. $a$ - зарисовка на Талимташ по Тoula (1890); $b$ - Войнишки камък (Талимташ) - изветрителни форми в еоценските пясъчници; $c$ - карстовият извор Котелка, на който е кръстен гр. Котел; $d$ - паметникът на Ивайловите воини, разбили византийците на 17 юли 1280 г. в прохода Железни врата (Демиркапия); e- отпечатък от амонит в стената на средновековната църква „Св. Троица“, доказващ произхода на строителните блокове от ценоманските пясъчници около вр. Коминчето; $f$ - фосилното находище на Orbitolina concava до шосето за Омуртаг; $g$ - Дряновската пещера; $h$ - пещерата Приказна; $i$ - защитената местност Орлова скала и входът към Орлова пещера; $j$ - водопадът Сини вир при с. Медвен; $k$ - скалният откос Орлица; $l$ - защитената местност Злостен; $m$ - пещерна ниша в Злостен; $n$ - Чобраташ с „жертвените вани“, които всъщност са естествени изветрителни форми в еоценските пясъчници 
Медвенският карст (s. l.) обединява няколко карстови феномена - скалния откос Орлицата, водопада Сини вир, Медвенските извори и пещерите Ледницата, Царевец, Черните извори, Маарата и Малката маара (фиг. 1j, k). Орлицата е със статут на природна забележителност още от 1968 г., а през 1984 г. околната местност с площ 566,5 ha е обявена за резерват с препорька да се разшири към местностите Злостен и Али Баба. През 2007 г. буферната зона е прекатегоризирана в защитена зона „Медвенски карст“ (s. s.).

Друг клъстер от геотопи е защитената зона „Злостен“ (фиг. 11, m), която представлява карстовата пропаст с пещерите Раковски, Академик, Мъгливата, Ужасът на иманярите, Субатть и Четиридесетте корита, и карстовите извори в Каядере. В отделен клъстер могат да се обединят скалните феномени северно от Котел - Юрушка стена, Войнишки камък (Талимташ), Чобраташ (фиг. 1n), пещерата Леденика“ с Римското кале и Върбишкия възсед, по който горнокредните варовици възсядат еоценските пясъчници.

Кипиловската група от геотопи се състои от разнообразни обекти - от преобладаващо ландшафтни като „Керсенлика“ в подържания резерват „Ардачлъка“, до културно-исторически, каквито са „Борината“ с късноантичното Кипиловско кале и средновековния Хърсовград. Останалите геотопи са еоценските скали с нумулити при с. Кипилово и картираните пещери в живописния проход Боаздере - Св. 40 мъченика, Големия извор и Козята пещера.

\section{Връзка на геологията с културното и духовно наследство}

Геотуризмът е важен елемент в стратегията на бъдещия геопарк. От особено значение е връзката на геологията с богатото културно и духовно наследство. През 18-19 в. Котел е важен културен и просветен център с развито занаятчийство. Тук са родени редица български възрожденци - П. Берон, Г. С. Раковски, Софроний Врачански и др. Възрожденската архитектура и историческите забележителности са го превърнали в предпочитана туристическа дестинация. Туристически селища са и архитектурният резерват „Жеравна“, където е родната къща на Й. Йовков, и Медвен с родната къща на 3. Стоянов. Битът и традициите на каракачанското малцинство, ежегодните празници на местните занаяти и фестивалът на фолклорните носии, представляващи непреходно културно наследство, оформят оригиналната идентичност на геопарка като единство между георазнообразие, вековна история и самобитна култура.

\section{Заключение}

Проучването на георазнообразието в община Котел доведе до идентифицирането на 44 геотопа, документирани по методиката за описание на геоморфосайтове, приложена в геопарк „Рила“ (Sinnyovsky et al., 2020). Добавянето на природен парк „Сините камъни“ и още 20-30 геотопа в Сливенския Балкан ще затвори главната тема и ще допълни георазнообразието с минерални извори, магмени и вулкански скали. Неразривната връзка между природно, културно и духовно наследство в площта е отлична предпоставка за разработване на геопарк „Източен Балкан“.

Благодарности: Настоящото изследване е осъществено в рамките на Договор ГПФ-233 на МГУ „Св. Иван Рилски“, съгласно Наредбата на $\mathrm{MOH}$ за финансиране на присъщата на държавните висши училища научна или художественотворческа дейност.

\section{Литература References}

Entscheva, M., I. Kănčev. 1961. Stratigraphische und Faunistische Forschungen in der Oberen Trias bei Kotel. - Ann. Dir. générale des rech. géol., A, 12, 41-96 (in Bulgarian with German abstract).

Kănčev, I. 1964. Le Crétacé supérieur du type medirerraneen dans le Balkan Oriental entre la passe Vratnik et de Rich. - Bull. inst. sci. de réch. géol., 1, 69-95 (in Bulgarian with French abstract).

Kanchev, I. 1995a. Geological Map of Bulgaria, Scale 1:100 000, with Explanatory Note. Map Sheet Sliven. Sofia, Geology and Mineral Resources Committee, Enterprise of Geophysical Survey and Geological Mapping, 155 p. (in Bulgarian with English abstract).

Kanchev, I. 1995b. Geological Map of Bulgaria, Scale 1:100 000, with Explanatory Note. Map Sheet Sungurlare. Sofia, Geology and Mineral Resources Committee, Enterprise of Geophysical Survey and Geological Mapping, 73 p. (in Bulgarian with English abstract).

Kockel, C. W. 1927. Zur Stratigraphie und Tektonik Bulgariens. Mit einem Beitrag von F. Kossmat. Das Grenzgebiet zwischen östlichen und zentralen Balkan.- Geol. Rundsch., Bd. 18, H. 5, 349-355.

Sinnyovsky, D., N. Kalutskova, N. Dronin, D. Sinnyovska, A. Medvedev, N. Telnova. 2019. Concepts of geoparks establishment in Bulgaria and their geothermal resources. - IOP Conf. Series: Earth Environ. Sci., 367, 012006, 1-15.

Sinnyovsky, D., D. Sachkov, I. Tsvetkova, N. Atanasova. 2020. Geomorphosite characterization method for the purpose of an aspiring geopark application dossier on the example of Maritsa Cirque Complex in Geopark Rila, Rila Mountain, SW Bulgaria. - Geoheritage, 12, 26, 1-17; DOI: s12371020-00451-w.

Toula, Fr. 1890. Geologische Untersuchungen im Östlichen Balkan und in den angrenzenden Gebieten. - Denkschr. Akad. Wiss. Wien, Abt. 2, Bd. 57, 323-400.

Zlatarski, G. 1905. Senonian formations in Eastern and partly in Central Balkan, and south of this mountain. - Period. Rev. Bulg. Liter. Soc., 66, 113-125 (in Bulgarian).

Zlatarski, G. 1906. Cenomanian stage in Eastern Balkan. Works Bulg. Natur. Soc., 3, 1-8 (in Bulgarian). 